\title{
Küyerelleşmenin Dijital Platformların İçerik Tanıtımına Etkisi: Netflix Örneği
}

\author{
Ümit Sarı (Dr. Öğr. Üyesi) \\ İstanbul Üniversitesi Illetişim Fakültesi \\ umitsari@istanbul.edu.tr \\ ORCID: 0000-0003-1761-3041 \\ Petek Sancaklı (Arş. Gör.) \\ Maltepe Üniversitesi Güzel Sanatlar Fakültesi \\ peteksancakli@maltepe.edu.tr \\ ORCID: 0000-0003-0063-4962
}

Başvuru Tarihi: 15.11.2019

Yayına Kabul Tarihi: 09.12.2019

Yayınlanma Tarihi: 24.01.2020

DOI: http://10.17680/erciyesiletisim.647463

\section{Öz}

Küreselleşme kavramı, Dünya'daki artan ekonomik faaliyetlerin ve teknolojik gelişmelerin bir sonucu olarak ortaya çıkmıştır. Bütüncül bir yapıyı işaret eden bu kavram, küresel boyutta gözlemlenebilen ortak beğenileri, zevkleri, alışkanlıkları, paylaşımları ve hatta değerleri de beraberinde getirmiştir. Teknolojik imkânlarla birlikte genişleyen pazar, git gide farklılıklara uyumlanma sürecini de hızlandıran bir yapıya bürünmüștür. Medyanın dijitalleşmesinin bir sonucu olarak dijital platformlar vasıtasıyla izleyicilere farklı düzeylerde deneyimleme ve katılım olanakları sunulmaya başlanmıştır. Bu bağlamda, izleyicilerin izleme alışkanlıklarına yönelik atılacak adımlar yeni yönelimleri beraberinde getirmektedir. Dijital platformların bu yeni yönelimlerinden biri olarak "Küyerelleșme" kavramı küreselleşme ve yerelleşme kavramlarının kombinasyonu şeklinde tanımlanmakta ve bu iki kavramın iç içe geçmesine karşılık gelmektedir. Araştırmada, günümüz dünyasında her geçen gün daha fazla konuşulan ve tartışılan "Küyerelleşme" kavramının Türkiye'deki dijital platformların içerik tanıtımlarına oluşturduğu etki, global bir dijital yayın platformu olan Netflix'in yapımlarına ait yerel tanıtımlar üzerinden irdelenmektedir. Kültürel kodlamalarıyla bu tanıtımlar, "Küyerelleşme" kavramının dijital platformların içerik tanımındaki etkisi, sunum ve tüketim dinamiklerini yansıtması bakımından önemli veriler sunmaktadır. Araştırma, bu tarz bir yerelleşmenin izleyicilerin, izleme alışkanlıklarında herhangi bir etkiye sahip olup olmadığını ortaya koymaktadır.

Anahtar Kelimeler: Küreselleşme, Küyerelleşme, Dijital platformlar, Netflix. 


\title{
The Effect of Globalizaton on Digital Platforms' Promotion of Content: The Netflix Example
}

\author{
Ümit Sarı (Asst. Prof. Dr.) \\ İstanbul University Faculty of Communication \\ umitsari@istanbul.edu.tr \\ ORCID: 0000-0003-1761-3041 \\ Petek Sancaklı (Res. Asst.) \\ Maltepe University Faculty of Fine Arts \\ peteksancakli@maltepe.edu.tr \\ ORCID: 0000-0003-0063-4962
}

Date Received: 15.11.2019

Date Accepted: 09.12.2019

Date Published: 24.01.2020

DOI: http://10.17680/erciyesiletisim.647463

\begin{abstract}
The concept of "Globalization" first arose from the ever-increasing worldwide commerce and technological advancements. The term, which refers to an inclusive framework; has brought forth observeable and shared tastes, delights, habits, shares and even values worldwide. The global market, which has grown considerably due to technological advancements, is ever-adapting itself at a faster pace to the constant differences that it encounters. As media digitalizes, consumers are now offered varying ways and levels of consuming media. Therefore, the next steps to be taken towards the global audience's viewing habits must include new directions of action. As one of the new directions of digital platforms; the term "Glocalization" appears as a combination of the terms "globalization" and "localization". Our research concerns the concept "Glocalization"; ever-increasingly discussed and argued upon in today's world, and its implications on content promotion of digital platforms will be elaborated upon the local promotions of Netflix, a global digital broadcasting platform. These broadcasts with their cultural undertones present us with very important knowledge concerning the effect of 'Glocalization' on digital content promotion and 'Glocalization's reflection on the dynamics of content presentation and consumption. The research determines if such localization attempts have any effect on viewer's consumption.
\end{abstract}

Keywords: Globalization, Glocalization, Digital platforms, Netflix. 


\section{Giriş}

İnsanlar arası iletişim, 21. yüzyılda yeni iletişim teknolojilerinin gelişmesi ile doruğa ulaşmıștır. Yeni iletişim teknolojileri ile birlikte ortaya çıkmıș bir kavram olan "Yeni Medya"nın hızı ve dinamiği sayesinde geleneksel medyaya kıyasla tüm kullanıcılar tek bir ortama taşınmaktadır. Gitgide küresel bir yapıya evrilen dünya, McLuhan'ın öne sürdüğü gibi coğrafi sınırların ötesine geçerek 'küresel köy' haline gelmektedir (Varol, 2017, 400). Gelişen yeni iletişim teknolojileri ve dijital çağ ile birlikte dünyanın farklı yerlerinde yaşayan insanlar, aynı anda aynı şeyleri izleyebilir, dinleyebilir ve okuyabilir duruma gelmiştir. $\mathrm{Bu}$ durum, üretilen içeriklerin dünyanın birçok noktasına ulaștırılmasının yanında, birçok farklı milletten insana da ulaşabilme imkânını doğurmuştur. Global markalar açısından değerlendirildiğinde, küreselleşme markaların dağıtım olanaklarına kolaylık sağlarken, ürünün aynı kategorideki farklı içeriklerin arasında kaybolma ihtimalini de arttırmaktadır. Global markalar için, böyle bir pazarda var olabilmek ve uzun soluklu bir üretim gerçekleştirebilmek daha özele inerek yerel çalışmalar yapmayı gerekli kılmıştır. Bu nedenle geliştirdikleri stratejilerden biri; Küreselleşmenin imkânlarını kullanarak, ürünün sunulacağı bölgenin değerlerini içeren ürünler ortaya koymaktır. $\mathrm{Bu}$ strateji, yalnızca global markaların değil medyanın ve global yayın organlarının da, daha çok izleyiciye ulaşmasında kullandıkları bir yöntem olarak karşımıza çıkmaktadır. Netflix gibi global markalar, farklı hedef kitlelerinin ilgisini çekebilmek ve bu ilgiyi izleme alışkanlığına dönüştürebilmek için o bölgenin yerel değerlerini içeren tanıtımlar yayınlamaya başlamıştır. Bu tanıtımlarla, o yapıma dikkat çekmek ve ilgiyi arttırmak hedeflenmektedir.

Araştırmada bu kapsamda, öncelikli olarak küreselleşme ve küyerelleşme kavramlarına değinilecektir. "İçerik tanıtımı" kavramı üzerinden global bir dijital yayın platformu olan Netflix'in Bright, Altered Carbon ve Black Mirror yapımlarının Türkiye'ye özgü olarak yapılmış olan yerel tanıtımlarının incelenmesi ve bu yerel tanıtımların izleyicilerin izleme alışkanlıklarında herhangi bir etkiye sahip olup olmadığının belirlenmesi, araştırmanın ana konusunu oluşturmaktadır. Yayınlanan tanıtımların izleyici üzerindeki etkisinin belirlenmesi amacıyla 30 kişiden oluşan bir grup katılımcı ile "Derinlemesine Görüşme" gerçekleştirilmiştir.

Araștırmanın kavramsal yapısı, elde edilecek amacın daha iyi anlaşılabilmesi dikkate alınarak belirlenmiştir. Bu doğrultuda çalışmanın bu bölümünde öncelikli olarak yeni medya, küreselleşme ve küyerelleşme kavramları açıklanacaktır. Ardından, Yeni İletişim Teknolojileri ve yeni medya kavramlarına değinilecektir.

\section{Yeni İletişim Teknolojileri ve Yeni Medya}

Yeni medya, günümüz dünyasında sıkça duyulan ve kullanılan bir kavramdır. Gündelik yaşamda, çoğu insanın kavramın içeriğine hakim olmadan kullandığı ve gündelik yaşamın bir parçası haline gelen yeni medya'nın ortaya çıkışı sayesinde, geleneksel medyada kullanılan medya araçların yanına birçok yeni iletişim teknolojileri eklenmiş, var olan geleneksel medya araçları dönüştürülerek medyaya farklı bir boyut kazanmıştır. Bu yeni teknolojiler sayesinde, içerik üreticisinin yönü tek taraflı olmaktan çıkıp, çoklu bir hal almıştır. Yeni medya ortamı; yeni medya teknolojisi ile büyüyen 1980 sonrası doğan y kuşağı ve 1995 sonrası teknolojik gelişmelerin içine doğan z kuşağının sıkça etkileşim halinde olduğu ancak az da olsa 1965 ve sonrasını ifade eden x kuşağının içinde bulunduğu bir ortamdır (McCrindle \& Wolfinger, 2009, s.10-12). 
Yeni medyanın keskin çizgiler ile belirlenmiş net bir çıkış tarihi bulunmamaktadır. Fidler'in de belirttiği gibi; 1980'li yıllara kadar gelişen teknolojinin geleneksel medyayı etkilemesi ve sonucunda ise geleneksel medyayı adım adım değiştirip dönüştürmesi ile bahsedilmeye başlanan bir kavramdır. Yeni medya kavramının oluşmasıyla birlikte, bu gelişmeler geleneksel medyayı tümüyle yok etmemiş aksine geliştirip dönüştürerek yeniliklere uyum sağlamasına ortam hazırlamıştır. (as cited in Aydoğan ve Akyüz, 2010, s. 53). Geray yeni medyaya, 'kitle izleyicisini bireysel kullanıcı olarak da kapsayabilen, kullanıcıların içeriğe veya uygulamalara farklı zaman dilimlerinde ve etkileşim içinde erişebildikleri sistemler' olarak bakmaktadır (2003,s.20). Lev Manovich'e göre ise, yeni medya olarak adlandırılan alanlar 'internet siteleri, sanal dünyalar (3D bilgisayar tarafından üretilen etkileşimli ortamlar), sanal gerçeklik (VR) multimedya, bilgisayar oyunlarl, interaktif kurulumlar, bilgisayar animasyonu, dijital video, dijital sinema ve insanbilgisayar arabirimleri'dir (2001, s.8-9).

İnternetin düzenlenmesi ve esnekleşebilmesini sağlamak için 'WWW' (World Wide Web/Dünya Çapında İnternet) uygulaması geliştirilmiştir. Bu uygulama, insanların internete istedikleri şekilde erişebilmesine ve içerik üretebilmesine imkân vermektedir (Castells, 2005, s.472).

Yeni medya, yayılımcı ve aynı zamanda melez bir yapıdan oluşmaktadır. Özellikle 2000'li yıllarda kullanılmaya başlanan bir kavram olan 'Yakınsama (bir araya gelme)', yeni iletişim teknolojilerinin sağladığı imkânlar doğrultusunda iletişim araçlarının ortak yönlerinin birbirleri içerisinde değerlendirilerek melez bir yapı oluşturulmasını ifade etmektedir. Bu melez yapı birçok yenilik doğurduğu gibi bazı teknolojilerin de çekiciliğini azaltmaktadır (İspir, 2013, s.15).

\section{Küreselleşme ve Küyerelleşme}

Küreselleşme, ortaya çıktığı 1960’lı yıllardan (İçli, 2001, s.163) bugüne değin sürekli olarak tartışılan ve çeşitli yaklaşımlara göre farklı şekillerde tanımlanan bir kavram olarak karşımıza çıkmaktadır. Kavram, bir terim olarak kullanılmasının yanı sıra aynı zamanda, günümüz dünyasını da içine alan bir dönemi ve süreci de ifade etmektedir.

Küreselleşme, ekonomik, politik, kültürel, toplumsal ve ideolojik boyutları olan çok yönlü bir sürece işaret etmektedir. Bu bağlamda kavramın, tek bir boyuta indirgenemez oluşu tanımlama noktasında da çeşitliliğe sebep olmaktadır. Manfred Steger, "Küreselleşme" adlı eserinde, çok çeşitli tanımlamalar bulunmasına karşın küreselleşme süreçlerinin sahip olduğu temel niteliklerin belirlenmesi noktasında araștırmacıların ortak tematik paydalarda buluşmakta olduğunu da öne sürmektedir. Steger bu kapsamda, beş farklı araştırmacı tarafından yapılmış küreselleşme tanımlamalarını ele alarak bu tanımlamaların farklı olmalarına rağmen küreselleşmenin temelinde yatmakta olan dört farklı özelliği ve karakteristiği ortaya koyduğunu belirtmiştir (Steger, 2013, s.27-29). Bauman'ın aktardığı üzere zaman ve mekân sıkışması kavramı, küreselleşme sürecinin çok yönlü olarak ilerleyen bir değişim süreci olduğuna işaret etmektedir. Böylelikle, Küreselleşme sürecinde zaman ve mekânın kullanımı hem keskin biçimde farklılaşmış hem de farklılaștırmıştır. Bu bağlamda Bauman küreselleşmenin, ne kadar birleştirirse o kadar böldüğünü, birleştirirken de bölmeyi sürdürdüğünü ve yerkürenin tektipleştiğini teşvik ettiğini savunmaktadır (Bauman, 2017, s.8).

Devletlerin, kamuoyunu etkilemekte olan küresel sorunları ele almakta yetersiz kalması sivil toplum kuruluşlarını, bu sorunların çözümü için gerekli sorumluluğu almaya 
yöneltmektedir. Böylece çeşitli alanlarda yardım amaçlı kurulan pek çok hükümet dışı örgüt, uluslararası arenada devletlerin yanında büyük bir güç haline gelerek küresel bir siyasi yapılanmanın önemli yapıtaşlarından birini oluşturmaktadır (Castells, 2004, s.419).

Bauman, kültürün küreselleşmesiyle birlikte iki farklı dünyanın ortaya çıktığını aktarmaktadır; Birinci dünyanın küresel çapta hareket edebilen ve mekânın kısıtlayıcı özelliklerinden arınmış olanlardan oluştuğundan bahsederken; ikinci dünyada ise hareket etmesi yasaklanmış ve yerel olarak bulunduğu yere bağlı olanları kapsayan bir dünya betimlemesi yapmaktadır. Küresel dünyada mekânsal sınırların yok oluşuna dikkat çeken "yersiz yurtsuzlaşma" kavramını da açıklayan Bauman, birinci dünyanın içinde bulunan küresel iş adamları, küresel akademisyenler ve küresel kültür yöneticileri işaret ederek, devletlerin sahip olduğu sınırların dünya malları, sermaye ve finansal faaliyetler için yok olduğunu öne sürmektedir. İkinci dünya sakinleri için ise göç kontrolü, oturma izni gibi küresel anlamda hareketi sınırlandıran katı yasalar ve politikalar üretilmeye devam etmektedir (Bauman, 2017, s.109-110).

Günümüzde internet, McLuhan'ın küresel köyünün başat aktörü olarak görülmekte ve ağlarla örülmüss küresel bir sistemin egemen olduğu ileri sürülmektedir. Bu bağlamda ortaya çıkan küresel bir ağ toplumuna ilişkin bir kavrayışı da ele alan McLuhan'a göre medyanın dijitalleşmesi ve internet, bireylerin düşünme, algılama ve kavrama biçimlerini de değiștiren önemli bir etmene dönüşmektedir (Ustakara, 2014, s.340).

$\mathrm{Bu}$ noktada medya, kültürel etmenlerin yayılmasında ve küresel bir kültürün yaratılmasında önemli rol oynamaktadır. Ancak bu küresel kültürün oluşumunda medya sahipliğini ve bir kültür yaratıp bunu yayabilme gücünü elinde bulunduran batı ülkelerinin kültür ve medeniyetine dair görünümler, gitgide ön plana çıkmaktadır. Dolayısıyla burada sözü edilen kültür, güçlü gelişmiş ülkeler tarafından diğerlerine empoze edilen bir kültür haline bürünmektedir (Yılmaz, 2007, s.507). Kültürel emperyalizm olarak adlandırılan bu süreç sonucu, toplumlar ya büsbütün kendi kültürlerini bırakıp empoze edilen küresel kültürü özümsemekte ya da kendi yerel kültürleri ile bu küresel kültürü sentezleyerek melez bir kültür oluşturma eğilimi göstermektedir.

Küreselleşme ile birlikte ortaya çıkan kültür emperyalizmine karşı yerel değerleri, yerel olanı ön plana çıkarmayı esas alan ve kültürün küreselleşmesi bağlamında ele alınması gereken bir diğer kavram "Küyerelleşme" kavramıdır. Küyerelleşme, küreselleşme ve yerelleşme kavramlarının kombinasyonundan ortaya çıkan bir kavram olarak nitelendirilmektedir ve ilk kez yetmişli yıllarda Japon işletmelerin, farklı bölgelere yayılmak ve bölgesel pazarlarda faaliyet göstermek amacıyla gerçekleştirdikleri uygulamalar sonucu ortaya çıkmıştır (Dilek ve Kaygalak, 2014, s.4). Dolayısıyla küyerelleşme, pazarlama odaklı bir yaklaşıma işaret etmektedir. Küresel olarak ortaya konmuş bir ürün ya da hizmetin, yerel özellikler, değerler ya da kültürel beklentilere göre adapte edilerek sunulmasına karşılık gelmektedir (Küyerelleşme, 2018). Küyerelleşme, diğer bir deyişle glokalleşme ya da glokalizm kavramı ile "yerel ile küreselin farklı coğrafi mekânlarda farklı sonuçlar doğuracak biçimde birbirlerine karşılıklı olarak nüfuz etmesi" vurgulanmaktadır (Büyükbaykal, 2014, s.80).

"Küresel düşün, yerel hareket et" anlayışını baz alarak yerel değerlerin kullanımını ifade eden küyerelleşme, uluslararası pazarlama ve işletmecilik açısından, farklı bölgelerde yer alan ve farklı kültürel değerlere sahip tüketicilerin mevcut taleplerine yanıt verebilmek amacıyla yerel değerlere ve yerel koşullara uygun olarak üretim ve pazarlama yapma sürecini içermektedir (Dilek ve Kaygalak, 2014, s.2). Dolayısıyla küyerelleşmede, küresel 
stratejiler doğrultusunda ortaya konan tek tip ürünler ya da tek tip iletiler yerine toplumların yerel özelliklerine göre ortaya çıkan tercih, talep ve ihtiyaçları doğrultusunda biçimlendirilen kişiselleştirilmiş ürünler ve iletiler yer almaktadır.

\section{Dijital Yayıncılık ve Netflix}

Geleneksel yayıncılıkta kullanılan analog yöntemlerden, kullanılacak dijital yöntemlere geçişi ifade eden dijital yayıncılık kavramı, ses ve görüntü unsurlarının bilgisayar ve internet teknolojileri vasıtasıyla birçok iletişim aracına aktarılmasına olanak sağlamaktadır. Sesin iletilmesinde, konvansiyonel yöntemlerden fiber optiklere ve ardından uydu yayıncılığına geçiş ile uygulanan dijital yayıncılık süreci, televizyon yayıncılığında etkisini 1980'li yıllarda göstermeye başlamış ve günümüze değin gelişimini sürdürmüştür. Dijital yayıncılığın yaygınlaşmasıyla birlikte dijital yayıncılık platformları da kurulmaya başlanmıştır.

1997 yılında Netflix'in kurulması ve evlere dvd dağıtımı olarak başlayan sistemini abonelik sistemine döndürmesiyle başlayan süreç ve günümüze kadar uzanmaktadır. Platform, 2017 yılı itibariyle şirketin içerik yatırımlarına 6 milyar dolar ayırmaktadır ve Eylül 2019 yılında içeriğinde 2300'den fazla film ve 1200'den fazla dizi bulunmaktadır (Netflix,2019). Netflix'in dünya pazarına yayılarak, büyük bir izleyici kitlesine ulaşmasının akabinde birçok şirket kendi dijital yayın platformlarını oluşturmaya başlamıştır. Netflix'in ardından ilk olarak Amazon ve hemen ardından YouTube Red, Amazon Prime, Hulu, MUBI ve Apple gibi şirketler öncelikle uluslararası pazara hemen ardından da Türkiye pazarına giriş yapmışlardır. Netflix'ten hemen sonra kendi dijital yayın platformunu oluşturan Amazon, Netflix benzeri bir platform olması ile dikkat çekmektedir. Prime'da, Netflix'te de olduğu gibi dizi ve filmler seçenekleri türlerine ayrılarak kullanıcının beğenilerine göre sıralanmakta ve her yapım için Türkçe altyazı seçeneği bulunmaktadır.

Dijital yayın platformlarının Türkiye pazarına girişi ise 2016 yılı itibariyle gerçekleşmiştir. İlk olarak 2016 yılının Ocak ayında Türkiye'deki kullanıcılarıma açılan Netflix'in ardından, Doğan Medya Grubu "Blu Tv"adlı platformu; Doğuş Grubu ise "Puhu Tv"yi kurmuştur. Türkiye'deki dijital yayın platformlarında Türkçe içerik üreten iki platform halen yayın hayatlarına devam etmektedir.

Netflix'in çalışma prensibi üyelik sistemine dayanmaktadır. Buna göre; üyeliklerin niteliği doğrultusunda kullanıcılar, Netflix'in bünyesinde bulunan dizi ve filmleri izleyebilmektedir. Üç farklı üyelik paketinin bulunduğu şirkette; üyelik özellikleriniz yapımları hızlı ve daha kaliteli izleme potansiyellerine göre ayrılmaktadır. Bu bağlamda; Temel, Standart ve Özel olmak üzere üç ayrı paket sistemi bulunmaktadır. Her paketin ayrı bir fiyat kategorisi mevcuttur ve izleyici elinde bulundurduğu paketin içeriğine göre dilediğince izleme gerçekleştirebilmektedir. Kullanıcılar bu paketlere üyelik gerçekleştirmeden önce pilot dönem olarak adlandırılan ilk ay için ücretsiz abonelik imkânına sahip olmaktadır. Buna ilave olarak şirket, kullanıcının sahip olduğu paketin niteliğine bakmaksızın, paket iptalini gerçekleştirmenize olanak sunmaktadır. Platform, kullanıcıların içeriklere daha kolay bir şekilde ulaşabilmesi için televizyon, iOS ve Android telefon ve tabletler, Windows telefon ve tabletler olmak üzere birçok cihazda kullanılabilmektedir. Ayrıca, Platformun bünyesinde kullanıcıya sunulan dizi ve videolar "Netflix Originals" olarak adlandırılmaktadır. Dünya'nın birçok farklı noktasında kullanıcılara ulaşan platform, 7 Ocak 2016 tarihinde Türkiye'ye pazarına giriş yapmıştır ve yayına başladığı ilk bir saat içerisinde 7000 kullanıcıyı bünyesine katmayı başarmıştır. Türkçe içerikler oluşturmaya başlayan platformun "Netflix Türkiye" bünyesinde yer alan yapımlarının tamamında 
Türkçe altyazı seçeneği bulunmaktadır ve bünyesinde Eylül 2019 yılında 2300'den fazla film ve 1200'den fazla dizi bulunmaktadır. Netflix İletişim Müdürü Arttanç Savaş 2019 yılının Aralık ayında yaptığı açıklamada platformun Türkiye'deki abone sayısının 1.5 milyonun üzerinde olduğunu ve abonelerin yüzde 77'sinin akıllı telefonlardan erişim sağladığını belirtti (Webtekno, 2019).

\section{Amaç ve Yöntem}

Araştırma kapsamında, dijital platformların küyerelleşme anlayışı bağlamında içerik ve ürünler ortaya koymasının tüketici tercihlerine olan etkilerinden yola çlkılarak, global bir dijital yayın platformlarından biri olan Netflix'in, Türkiye'ye has kültürel kodlamaları kullanarak kişiselleştirilmiş içerikler yayınlamasının, Türkiye'deki izleyiciler üzerinde yarattığı etkinin araştırılması amaçlanmaktadır.

Çalışmada kalitatif ve kantitatif yöntemler ardışık olarak kullanılmıştır. Buna göre, kalitatif yöntem olarak "araştırılan konunun, tüm boyutlarını kapsayan, daha çok açık uçlu soruların sorulduğu ve detaylı cevapların alınmasına imkan tanıyan, yüz yüze birebir görüşülerek bilgi toplanmasını sağlayan bir veri toplama yöntemi" (Tekin, 2006, s.101) olarak tanımlanan ve yarı yapılandırılmış soru formu ile uygulanan yüz yüze derinlemesine görüşme yöntemi kullanılmıştır. Derinlemesine görüşmeler, cinsiyet, yaş, eğitim ve sosyal durum özellikleri dikkate alınarak önceden belirlenmiş 15 kadın, 15 erkek toplam 30 katılımcı ile her bir katılımcıya en az 20 dakika en çok 40 dakika ayrılarak gerçekleştirilmiştir.

Görüşme sırasında sorulacak sorular, yarı yapılandırılmış yüz yüze derinlemesine görüşme soru formu ile görüşme esnasındaki doğal akışı bozmayacak biçimde önceden belirlenmiștir. Görüșme formunda yer alan sorulardan ilk sekizi, tanıtım filmlerinin izletilmesinden önce, kalan dört sorusu ise tanıtım filmleri katılımcıyla birlikte izlendikten sonra sorulmuştur. Buna göre katılımcıların sosyal durumlarının, genel olarak izleme alışkanlıkları ile örneklem olarak seçilen ve tanıtım filmleri izletilen üç yapım için haberdar olma, ilgi, beğeni, uygunluk ve izleme davranışının söz konusu olup olmadığının ölçülmesinin amaçlandığı derinlemesine görüşme soruları şöyledir:

1. Bize kendinizi tanıtır mısınız?

2. Film izliyor musunuz? Ne sıklıkla?

3. Dizi izliyor musunuz? Ne sıklıkla?

4. Dizileri hangi platformlardan izliyorsunuz?

5. Youtube üzerinden izlemeler yapıyor musunuz? Hayırsa neden?

6. Neler izliyorsunuz?

7. Netflix'ten haberdar misiniz?

8. Bright filmi ile "Altered Carbon ve Black Mirror" dizilerini biliyor musunuz?

9. Bu diziler izleme alışkanlıklarınıza uygun mu? Hayırsa neden?

10. Bu dizilerle ilgileniyor musunuz? Hayırsa neden?

11. Bu dizileri beğeniyor musunuz?

12. Bu diziyi izler misiniz? (Tanıtımlar izletildikten sonra)

Katılımcıların sorulara verdiği cevaplar, video kayıt, ses kaydı veya yazı ile kayda alınmıştır.Araştırma kapsamında kantitatif yöntem olarak, Netflix Türkiye tarafından önce resmi YouTube sayfasında sonrasında ise Twitter, Facebook ve Instagram hesaplarında paylaşılan tanıtım filmlerinin her bir sosyal medya platformunda aldığı beğeni, paylaşım, yorum ve görüntülenme sayılarının analiz edilmesi ile sayısal veriler elde edilmiştir. 
Araștırma kapsamında, dizi ve film türünde yerli ve yabancı her türlü yapımı izleyen tüm kadın ve erkekler araștırmanın evrenini oluşturmaktadır. Çalışma gereğince tüm evrenin araștırmaya dâhil edilmesinin mümkün olmamasından dolayı evreni temsil edecek bir örneklem grubu belirlenmiş, araştırmanın problemine uygun verilerin toplanmasında bu örneklem grubu ile çalışılmıştır. Örneklem grubunun belirlenmesinde yaş, cinsiyet, eğitim durumu gibi demografik özelliklerin yanı sıra sosyal medyayı etkin bir biçimde kullanıyor olması, ayda bir kereden daha fazla sıklıkta film izlemesi, araştırma kapsamında etkileri araştırılan tanıtım filmlerinin orijinal dizi ve film versiyonlarını daha önce izlememiş olması gibi sosyal durumla ilgili nitelikler de dikkate alınmıștır. Bu bağlamda araștırmanın örneklemi, 17-47 yaş arası kadın ve erkekler arasından seçilmiş; eğitim düzeyleri en az lise en çok lisansüstü olacak şekilde belirlenmiştir. Araştırmaya katılan tüm katılımcıların demografik özellikleri tablodaki gibidir:

Tablo 1: Örneklemin demografik özellikleri

\begin{tabular}{|c|c|c|c|c|c|}
\hline & CINSIYET & YAŞ & EĞiTiM DURUMU & MEDENI HAL & MESLEK \\
\hline $\mathrm{K} 1$ & Kadın & 26 & Lisans & Evli & Kimyager \\
\hline $\mathrm{K} 2$ & Kadın & 25 & Yüksek Lisans & Bekâr & Öğrenci \\
\hline K3 & Kadın & 24 & Ön Lisans & Bekâr & Muhasebe Sorumlusu \\
\hline K4 & Erkek & 25 & Yüksek Lisans & Bekâr & Öğretmen \\
\hline K5 & Erkek & 28 & Lisans & Evli & Uçak Teknisyeni \\
\hline K6 & Kadın & 24 & Lisans & Bekâr & Öğretmen \\
\hline K7 & Erkek & 38 & Lisans & Evli & Muhasebe Sorumlusu \\
\hline K8 & Kadın & 36 & Lisans & Evli & Çalışmıyor \\
\hline K9 & Kadın & 27 & Yüksek Lisans & Bekâr & Öğrenci \\
\hline K10 & Erkek & 24 & Lisans & Bekâr & Polis \\
\hline K11 & Kadın & 22 & Lisans & Bekâr & Öğrenci \\
\hline K12 & Erkek & 22 & Lisans & Bekâr & Öğrenci \\
\hline K13 & Kadın & 25 & Lisans & Bekâr & Gümrük Müşavir Yardımcısı \\
\hline K14 & Kadın & 23 & Lisans & Bekâr & Kurgu Operatörü \\
\hline K15 & Erkek & 17 & Lise & Bekâr & Öğrenci \\
\hline K16 & Erkek & 18 & Lisans & Bekâr & Öğrenci \\
\hline $\mathrm{K} 17$ & Kadın & 24 & Lisans & Bekâr & Öğrenci \\
\hline K18 & Erkek & 22 & Lisans & Bekâr & Çalışmıyor \\
\hline K19 & Erkek & 42 & Lisans & Bekâr & Çalışmıyor \\
\hline K20 & Erkek & 25 & Lisans & Bekâr & Çalışmıyor \\
\hline K21 & Erkek & 25 & Yüksek lisans & Bekâr & Sosyal Medya Uzmanı (Puhutv) \\
\hline K22 & Erkek & 29 & Doktora & Bekâr & Devlet Tiyatrocusu \\
\hline K23 & Erkek & 25 & Lisans & Bekâr & Endüstri Mühendisi \\
\hline K24 & Erkek & 27 & Yüksek Lisans & Bekâr & Yazılım Mühendisi \\
\hline K25 & Erkek & 25 & Yüksek Lisans & Bekâr & Kameraman \\
\hline K26 & Kadın & 25 & Yüksek Lisans & Bekâr & İnsan Kaynakları Stajyeri \\
\hline K27 & Kadın & 27 & Yüksek Lisans & Bekâr & Çiçekçi \\
\hline K28 & Kadın & 27 & Yüksek Lisans & Bekâr & Reklamcı \\
\hline K29 & Kadın & 47 & Lisans & Evli & Tarih Öğretmeni \\
\hline K30 & Kadın & 25 & Lisans & Bekâr & Türk Edebiyatı Öğretmeni \\
\hline
\end{tabular}

\section{Bulgular ve Sonuç}

Bulgular kısmının alt başlığı olarak derinlemesine görüşme bulgularının yer aldığı bölümde, katılımcıların isimleri gizlenerek 'K1, K2, K3, K4, K5, K6, K7...' şeklinde 
kodlanarak belirtilmektedir. Araștırmanın bu bölümünde katılımcılarla yapılan görüşmeler sonrası elde edilen verilere ait bulgulara, görüşmelerde sorulan sorularla birlikte yer verilmektedir.

\subsection{Bulgular}

\subsubsection{Derinlemesine Görüşme Bulguları}

Bulgular kısmında araștırmaya katılan on beş erkek ve on beş kadın katılımcıya yüz yüze yapılan derinlemesine görüşmede sorulan soruların yanıtlarına yer verilmektedir. Katılımcılara ilk soru olarak kendilerini tanıtmaları istenmiștir. Bu sorunun yanıtlarına örneklem kısmında bulunan tabloda yer verilmiştir.

Araştırmada bulunan katılımcıların dizi izleme alışkanlıklarını saptamak için sorulan soruya on beş erkek katılımcıdan on ikisi haftada en az bir olmak üzere ortalama olarak iki-üç bölüm seyretmektedir. Diğer üç erkek katılımcı dörtten fazla izlediklerini söylemiștir. Kadın katılımcılardan ise sekizi haftada en az bir bölüm ortalama olarak iki iç bölüm izlediğini belirtirken, bir kadın katılımcı neredeyse her gün izlediğini, başka bir katılımcı haftada beş bölüm izlediğini, iki katılımcı da haftada dört bölüm izlediğini belirtmiştir. Son üç kadın katılımcı da haftada bir bölüm dizi izlediğini ifade etmiștir.

Katılımcılar film izleme sıklıklarına çeşitli ölçeklerde cevaplar vermişlerdir. Soru yöneltilen on beş erkek katılımcıdan altısı haftada bir film izlemektedir. İki erkek katılımcı iki, diğer üç erkek katılımcı üç film izlemektedir. Geriye kalan dört erkek katılımcıdan üçü ayda ikiüç, diğeri ise ayda ortalama on film izlemektedir. Kadın katılımcılardan dördü haftada bir, iki katılımcı iki, iki katılımcı üç film izlediğini belirtmektedir. Sadece bir kadın katılımcı haftada ortalama beş film izlediğini belirtmiştir. Geri kalan altı kadın katılımcıdan üçü ortalama olarak ayda iki-üç film izlediğini, üçü ise üç-dört film izlemektedir.

İzleme yaptıkları platformlar sorulduğunda ise; erkek katılımcılardan on üçü sadece online izleme yaptığını belirtirken, sadece ikisi hem online hem de geleneksel medya olan televizyondan vazgeçemediğini belirtmiştir. Online izleme yapan erkek katılımcılardan on üçü Youtube ve Puhu Tv gibi ücretsiz izleme platformlarını tercih etmektedir. Diğer iki katılımcıdan birisi sadece ücretli online izleme platformlarını kullanırken diğeri ise hem ücretli hem de ücretsiz online izleme platformlarından yararlanmaktadır. Kadın katılımclardan sekizi; sadece online izleme yaptığını geriye kalan yedisi ise hem online hem de televizyondan izleme yaptıklarını söylemiștir. Kadın katılımcılardan da sadece ikisi hem ücretli hem ücretsiz online dizi izleme platformlarını tercih ederken, başka bir katılımcı televizyonda ücretli izleme yapmayı tercih ettiğini ifade etmiștir.

Beșinci olarak sorulan Youtube kullanma pratiğine yönelik soruya cevap bütün katılımcılar aktif bir şekilde kullandıklarını ifade etmişlerdir. Bu soruyu takiben ne tarz izlemeler gerçekleştirdiklerine yönelik soruya ise kişisel zevk ve beğenilere göre çok çeşitli cevaplar alınmıştır. Kadın katılımcılar makyaj, komik videolar, müzik klipleri, dans videoları, diziler, haber, canlı yayın, cilt bakım videoları, yemek tarifi videoları izlediklerini belirtirken, erkek katılımcılar ise müzik klipleri, komik videolar, meslekleri ile ilintili seriler, program tekrarları, diziler, teknoloji, otomobil, haber, sinema ile ilgili içerikleri izlediklerini ifade etmişlerdir. Toplam otuz katılımcıdan dokuzu erkek, dördü kadın olmak üzere toplam on üç katılımcı özel olarak dizi/film tanıtımlarını takip ettiklerini ifade etmiştir.

Katılımcılara Netflix'ten haberdar olup olmadıkları sorulduğunda katılımcılardan bir kadın katılımcı haricinde, yirmi dokuz katılımcı Netflix'ten haberdar oldukları cevabını 
vermiştir. Ancak haberdar olan yirmi dokuz katılımcıdan sadece iki erkek katılımcı uzun süredir Netflix üyeliği sahibi olduklarını bildirmiștir.

Çalışmada konu edilen örneklemlerden haberdar olup olmadıkları sorulduğunda erkek katılımcıdan yedisi üç yapımın tamamından da haberdar olduğunu belirtmiştir. Dört erkek katılımcı da sadece Bright ve Black Mirror yapımlarından haberdarken, iki katılımcı sadece Black Mirror'dan haberdar olduğunu söylemiştir. Geriye kalan iki erkek katılımcı ise yapımların hiçbirinden haberdar olmadığını ifade etmiştir. On beş kadın katılımcıdan altısı yapımların üçünden de haberdar olduğunu bildirmiştir. Diğer katılımcılardan dördü sadece Black Mirror'dan haberdar olduklarını söylemiştir. Beş katılımcı da yapımların hiçbirinden haberdar değildir. Çalışmaya katılan on beş kadın ve on beş erkek katılımcıdan yapımlardan haberdar olan katılımcılar da dahil olmak üzere hiçbiri çalışmaya konu edilen örneklemleri izlememiş olduğunu söylemektedir.

Katılımcılarla yapılan görüșme sonucunda alınan cevaplara göre 30 katılımcıdan toplamda sekiz tanesi, bu dizilerin tamamının izleme alışkanlıklarına uygun olmadığını dile getirirken; sebebi ise yapımların fantastik bulunması, tür olarak katılımcının beğeni ve zevklerine hitap etmemesi, tanıtımların diziyi anlatmada ve tanıtmada yetersiz bulunması, dizilerin konularının anlaşılır olmaması ve dizi sürelerinin uzunluğu şeklinde belirtmiştir.

Toplamda on katılımcı ise, bu dizilerin izleme alışkanlıklarına uygun olduğunu ve bu dizileri izleyebileceğini belirtmiş; geriye kalan on iki katılımcıdan beşi yalnızca Altered Carbon dizisinin, ikisi yalnızca Black Mirror'ın izleme alışkanlıklarına uygun olduğunu dile getirmiştir. Kalan beş katılımcıdan dördü ise hem Altered Carbon hem de Black Mirror'ın izleme alışkanlıklarına uygun olduğunu ancak Bright'ın hiçbir şekilde izleme alıșkanlıklarına uygun bir yapım olmadığını söylemiștir. Bunun yanı sıra katılımcılar arasından K23, bu dizilerin izleme alışkanlıklarına uygun olup olmadığının anlaşılması için her bir dizinin en az bir veya iki bölümünün izlenmesi gerektiğini belirtmiş ve kesin olarak olumlu ya da olumsuz bir yanıt vermemiștir.

Yapılan araştırma kapsamında, Türkiye özelinde tanıtımları gerçekleştirilen dizilere ve filme yönelik izleyici ilgisinin ölçülmesini amaçlayan soruya, 30 katılımcının yalnızca altısı, üç yapımın hepsiyle ilgilendiği yanıtını vermiştir. Katılımcıların, çoğunlukla yalnızca Black Mirror veya yalnızca Altered Carbon ile ilgilendiğinin gözlemlendiği soruya yalnızca iki katılımcı "sadece Bright ile ilgileniyorum" şeklinde cevap vermiştir. Soruya tamamen olumsuz yaklaşan katılımcılar ise bu yapımların hiçbiri ile ilgilenmediklerini, hiçbir yapımı ilgi çekici bulmadıklarını belirtmişlerdir.

Çeşitli yaş gruplarından ve farklı meslek gruplarından seçilen otuz kişilik ekiple yapılan derinlemesine görüşmelerden elde edilen bilgilere göre on beş erkek katılımcıdan yedisi yalnızca "Altered Carbon" dizisi için izleme gerçekleştirebileceğini söylemiştir. Bu yedi kişiden beşi izletilen üç dizinin tanıtımlarını beğenmediğini dile getirirken, kalan ikisi üç yapımın tanıtımlarını da beğendikleri halde konusu ve işlenişi bakımından yalnızca "Altered Carbon"u izleyeceklerini aktarmışlardır.

Kalan sekiz kişilik diğer erkek katılımcının ise üçü tanıtımlar izletildikten sonra "Bright" filmini merak ettiklerini ve izleme gerçekleştireceklerini dile getirmişlerdir. $\mathrm{Bu}$ üç katılımcıdan ikisi üç tanıtımı da sevdiklerini belirttikleri halde yalnızca "Bright" için izleme gerçekleştireceklerini söylemişlerdir. Kalan bir kişi ise yalnızca kültürel kodlamalarından dolayı tanıtımının başarılı bir şekilde işlendiğini düşündüğü için "Bright" filmini 
izleyebileceğini dile getirmiştir. Erkek katılımcılardan ikisi tanıtımları başarılı bulmadığı halde konusunu beğendikleri ve varoluşsal sorgulamalar taşıdıklarını düşündükleri için "Black Mirror" dizisi üzerine bir izleme gerçekleştireceklerini söylemişlerdir. Son olarak üç katılımcı da tanıtımları beğenmediklerini fakat içerik itibariyle ilgi çekici olduklarını düşündükleri için "Altered Carbon" ve "Black Mirror" dizilerini izleyebileceklerini dile getirmişlerdir. Otuz kişilik katılımcı grubunun diğer yarısını oluşturan on beş kadın katılımcıdan elde edilen sonuçlar irdelendiğinde yedi katılımcının tanıtımı izletilen yapımlardan yalnızca "Altered Carbon"u izleyecekleri ortaya çıkmıştır. Bu yedi kişiden ikisi tüm tanıtımları beğenmelerine rağmen izleme eğilimi çerçevesinde tercihini "Altered Carbon"dan yana kullanmıştır. İki katılımcı tanıtımları başarısız buldukları halde içerik olarak merak ettiklerini dile getirdikleri "Bright" adlı yapımı izleyeceklerini dile getirmişlerdir.

İki tanesiyse bütün tanıtımları oldukça başarılı bulduklarını ve yapımların üçünü de izleyebileceklerini dile getirmişlerdir. Katılımcılardan yalnızca biri tanıtımları beğenmediği halde tümüyle mistik havasından dolayı "Black Mirror" üzerine izleme gerçekleştireceğini dile getirmiştir. Son olarak katılımcılardan üçü tanıtımları oldukça basit içerikli ve aslından uzak bulmuş bu sebeple tanıtımı gösterilen üç yapımı da izlemeyeceğini dile getirmiştir.

\subsubsection{Sosyal Medya Etkileşim Sayıları}

Global bir dijital yayın platformu olarak Netflix'in, küyerelleşme bağlamında incelenebilecek Türkiye'ye özel kültürel kodlar ile hazırlanmış tanıtım filmleri, Netflix'in resmi Türkiye hesabı tarafından çeşitli sosyal medya platformlarında paylaşılarak yayınlanmaktadır. Araștırma kapsamında, bu tanıtım filmlerinin izleyicilerde yarattığ etkinin sosyal medyaya yansımasını ortaya koymak amacıyla, yapılan paylaşımların etkileşim sayıları incelenmiştir. Bu bağlamda Netflix, 22 Aralık 2017 tarihinde öncelikli olarak Youtube'daki resmi Netflix Türkiye hesabında, ardından da Twitter ve Facebook'taki resmi hesaplarında, piyasaya sürülecek Bright filminin, Türk versiyonu olan "Orklar Aramızda" isimli tanıtım filmini yayınlamıștır. Filmin orijinal karakterleri olan orkların, kokoreççi, berber, mahalle sakini, araba tamircisi vs. olarak gösterildiği filmi oldukça beğenilmiş; en son 15 Kasım 2019 tarihinde alınan verilere göre Youtube'da 29 bin, Facebook'ta 150 bin, Twitter'da 12 bin ve Instagram'da 30.125 beğeni alarak Netflix'in Türk versiyonu yapımları arasındaki en fazla beğeniyi alan gönderi olmuştur. Paylaşım, YouTube'da 1.6 bin yorum alırken, 545.359 görüntüleme sayısına ulaşmış; Facebook'ta ise 5300 yorum, 9800 paylaşım ve 3.5 milyon görüntüleme almıştır. Twitter'da ise 237 yorum, 2492 retweet ve 373 bin görüntüleme alan paylaşım Instagram ise 744 yorum ve 355.912 görüntülemeye ulașmıștır.

Hemen ardından Netflix, 14 Ocak 2018 tarihinde YouTube, Facebook, Instagram ve Twitter'da olmak üzere eş zamanlı olarak Black Mirror'un Esra Erol ile çekmiş olduğu Türkiye özel versiyonunu paylaşmıştır. Paylaşım, en son 15 Kasım 2019 tarihinde alınan verilere göre, YouTube'da 204 beğeni, 73 yorum ve 48 bin görüntüleme sayısına ulaşmıştır. Facebook'ta yine aynı tarihte alınan verilere göre 2500 beğeni, 516 yorum, 249 bin görüntüleme alan gönderi, 445 kullanıcı tarafından yeniden paylaşılmıştır. En fazla görüntülenme sayısına Twitter'da ulaşan yapım, 753 bin görüntülenme almış; bunun yanında 6510 beğeni, 1212 yorum ve 1080 retweete ulaşmıştır. Son olarak Instagram'da 6327 beğeni, 756 yorum ve 104.674 görüntüleme alan paylaşım Twitter'dan sonra en çok Instagram'da yorum almıştır. Netflix'in 2 Şubat 2018 tarihinde tüm resmi sosyal medya hesaplarından eşzamanlı olarak takipçileriyle paylaştığı son tanıtım filmi Altered Carbon 
dizisinin Türkiye’ye özel tanıtım filmi olmuştur. Melik Duyar'ın yer aldığı tanıtım filmi, 15 Kasım 2019 itibariyle YouTube'da 1500 beğeni, 145 yorum ve 70 bin görüntüleme sayısına ulaşmıştır. Son olarak Netflix Türkiye'ye ait Instagram hesabından da paylaşılan gönderinin bu platformdaki beğeni sayısı 4695, yorum sayısı 266 ve görüntüleme sayısı ise 64.586 olarak kaydedilmiştir.

\subsubsection{Tanıtımların Barındırdığı Kültürel Kodlara Göre Belirlenmesi}

\subsubsection{Esra Erol'lu Black Mirror}

Black Mirror (Kara Ayna) ilk olarak İngiliz televizyon kanalı Channel 4'da 2011 yılında yayınlanmaya başlanan bir dizidir. İkinci sezonu 2013 yılında yayınlandıktan sonra 2015 yılında Netflix tarafından satın alınan dizinin üçüncü sezonu 2016, dördüncü sezonu 2017 yılında ve son olarak beşinci sezonu15 Mayıs 2019 tarihinde yayınlanmış olan, halen devam eden bir dizidir (Welsh, 2018). Yaratıcısının Charlie Brooker olduğu dizinin yayınlanmış 22 bölümü bulunmaktadır (Netflix, n.d.). Yapım,İnsanlığın yakın bir gelecekte karşılaşabileceği daha çok teknolojiye dayalı sorunları anlatan distopik bir çalışma içermektedir. Her bölümün farklı bir yönetmen tarafından kameraya alınması ve farklı senaristler tarafından kağıda dökülmesi yapımı izleyici için çekici hale getirmektedir. Yapımda her bölüm, farklı bir oyuncu kadrosuyla çekilmektedir. $\mathrm{Bu}$ anlamda yapımda, izleyici karşısına çıkan belirli isimlerden bahsetmek mümkün olmamaktadır. Black Mirror'ın araștırma kapsamında ele alınan Türkiye tanıtımı 2018 yılının ocak ayında Netflix Türkiye'nin Twitter sayfasında yayınlanmıştır. Tanıtımda Türkiye'de son dönemlerde büyük bir yer tutan ve aynı zamanda büyük tartışmalara da kaynak olan izdivaç programı konseptinden yararlanılmıştır. Dizi, konusu gereği insanlığın yakın gelecekte karşılaşabileceği sorunları ele alması nedeniyle izdivaç programlarının gelecekte nasıl bir şekle dönüşebileceğine üzerinden izleyicilerin ilgisini çekmeyi amaçlamaktadır. Tanıtımda önce izdivaç programlarında sıkça görüldüğü gibi genç bir çift lokantada birbirlerini tanımaya çalışmaktadır. Anlaşamayan çift daha sonra simülasyonun bozulmasıyla stüdyoya, Esra Erol’un yanına dönmektedir.

Kendileri anlaşamayan çiftin durumunu stüdyoda bulunan seyircilerin akıllı telefonlarıyla verdiği oylar ve bir dijital uygulama karakteri olan Şirin Ana belirlemektedir. Kararın olumsuz çıkmasının ardından genç kızın başladığı şarkıya stüdyodaki herkesin eşlik etmesiyle tanıtım sona ermektedir. Senaryoya bakıldığında, tanıtımda Türkiye'de yayınlanan herhangi bir izdivaç programının akışına yer verildiği görülmektedir. Mekân olarak Türkiye'deki izdivaç programlarına benzer bir stüdyo tercih edilmiştir. Ancak dizinin orijinal mekanlarına sadık kalınarak simülasyon, akıllı telefonla oy verme gibi ileri teknoloji unsurlarına da tanıtımda yer verilmektedir. Tanıtımda izdivaç programı sunucusu olarak Türkiye'de bir dönem izdivaç programı sunmuş olan Esra Erol tercih edilmiştir ve Erol'un Türkiye'deki tanınırlığından yararlanılarak ve izdivaç programlarının popülerliğinden faydalanılmak istenmiştir. Tanıtımda seçilen kadın ve erkek oyuncu da daha önce izdivaç programlarında sansasyonel olmuş karakterlerin bir birleşimi olarak oluşturulmuştur. Tanıtımda kullanılan bütün karakterler orijinal karakterlerden bağımsız olarak kültürel kodlarla çevrelenmektedir. 'Nasibimsin.' 'Kısmet değilmiş.' gibi yer yer kültürel ifadelere rastlanan diyaloglar kullanılmıștır. Müzik olarak da Türkçe bir müzik tercih edilmiştir. Tanıtımda kostüm seçimi, genel konsepte bağlı kalınarak tümüyle kültürel unsurlar dikkate alınarak oluşturulmuştur.

Senaryodan başlayarak, oyuncular, kıyafetler, diyaloglar, mekân ve müziklere kadar uzanan tüm unsurlar tamamen kültürel kodlar dikkate alınarak tasarlanmış ve tanıtımın 
tamamında kullanılmıştır. Tanıtımın orijinal dizi ile bağlantısı sadece filmin distopik düşüncesini yansıttığı ana teması ve kullanılan ileri teknoloji unsurlarıdır.

\subsubsection{Altered Carbon}

Altered Carbon (Değiștirilmiş Karbon), İngiliz bilim kurgu yazarı Richard K. Morgan'ın 2002 yılında yayınladığı aynı adlı romanından uyarlanan ve şu ana dek bir sezon ve toplamda on bölüm yayınlanmış Netflix dizisidir. Dizi, 25. Yüzyılda gerçekleşmekte olan zihin ve ruh transferlerini konu alır. İnsanın zihninin dijitalleștirilebilir olması ve ruhların başka bedenler arasında transfer edilebilmesi durumunda neler olacağını konu edinmektedir (Altered Carbon, 2019).

Dizinin tüm dünyada Netflix tarafından yayınlanan orijinal fragman ve tanıtım filmlerinin yanı sıra Netflix'in Türkiye özelinde kültürel kodlamalar ile tanıdık figürlere yer vererek hazırladığı tanıtım filmi 2018'in şubat ayında Netflix Türkiye'nin resmi sosyal medya hesaplarında yayınlanmıștır. Tanıtım, Altered Carbon dizisinin Türkiye'ye uyarlanmış kısa bir versiyonu şeklindedir. Tanıtımda kullanılan kültürel kodların neler olduğuna bakıldığında göze çarpan ilk detay, hafızanın dijitalleştirilip ruhla birlikte farklı bedenlere transferini konu alan tanıtım filminde, Türkiye'de "dünya fotografik hafıza ve bilinç şampiyonu" olarak bilinen ve bir dönem Türk medyası tarafından "unutmayı unutan adam" olarak da adlandırılan Melik Duyar'a yer verilmesi olmuştur (Melik Duyar Kimdir, 2018).

Melik Duyar'ın dizinin orijinal versiyonunda yer alan zihin transferi ve beden değişim programını anlattığı tanıtım filminde, tamamı Türk oyunculardan oluşan karakterler kullanılmıștır.

Filmde, Melik Duyar'ın bilinç transferi programını anlatmasının ardından programı denemek ve bilincini daha genç ve güzel bir bedene aktarmak isteyen ana karakterlerden Gamze Ögüt isimli karakter, altmışlı yaşlarında evli bir kadındır. Gamze'nin bilinç transfer işlemi, orijinal senaryoya uygun olarak para karşılığında uygun bedenin seçilmesi ve bilincin dijital kasetlere aktarılarak yeni bedene transfer edilmesi şeklinde gerçekleşmektedir. Transfer işleminin gerçekleşmesinin ardından yeni bedenine kavuşan karakterin, "şimdi Necati düşünsün" diyerek eşinden bahsettiği diyalog, filmin dikkat çeken bir başka yerel unsurudur.

Filmde kullanılan kostümlerde hem orijinal versiyona sadık kalınmış hem de karakterlerin günlük hayatta giydikleri kıyafetlerle dizinin orijinal versiyonunda olmayan farklı bir atmosfer yaratılmıştır.

Öte yandan filmde orijinal karakter kullanımları da görülmektedir. Programa gelenleri karşılayan ve beden transfer işleminin gerçekleşmesini koordine eden birbirine benzer iki kadın karakter, filmin orijinal versiyonunda da kullanılmakta olan karakterlerdir. Filmde kullanılan en önemli yerel unsur "dil"dir. Tamamen Türkçe diyalogların yer aldığı sahneler, Türkçe alt yazıyla da desteklenmiştir.

Mekânların seçiminde ise dizinin orijinal versiyonuna sadık kalınarak yapay olarak oluşturulmuş benzer mekanlar kullanılırken, seçilen müzikler ve ses efektleri de orijinal versiyona uygun olarak oluşturulmuştur. 


\subsubsection{Orklar Aramızda / Bright}

2017 yapımı bir Netflix projesi olan, 1 saat 16 dakika süreli olarak ve +16 etiketiyle yayına giren "Bright", Netflix'in yayın haklarını satın aldığı ilk geniş bütçeli film olarak öne çıkmaktadır. Fantastik bilimkurgu ekseninde bir tür olan yapım; geleceğin dünyasında bir arada yaşayan orklar, elfler, periler ve insanların dünyasında bir polis memurunun (Will Smith) başından geçen seri olaylar anlatılmaktadır. Netflix Türkiye'nin kendi resmi sitesinden ve ardından resmi sosyal medya hesaplarından olduğu "OrklarAramızda" etiketiyle peş peșe yayınlamış olduğu tanıtımda, Türkiye’ye özgü kültürel kodlamalara yer verilmektedir. Tanıtımın başat karakteri olarak, dizide de ana karakterlerden biri olan "ork"lar merkeze alınmaktadır. Tanıtımda, hikâyenin geçtiği yer olarak İstanbul gösterilmektedir. Orklar, saç traşı yapan berber Orkut olarak, Ork mahallesinin gençleri, tamirci çırağı, seyyar satıcı ve kahvehanede tavla oynayan ortayaşlı bir karakter olmak üzere çeşitli formlarda tasvir edilmektedir. Tanıtımda yer alan türklere özgü kültürel kodlamalar ele alındığında; Türk kültürüne özgü olarak dikkat çeken "çay" öğesi,"güvercin uçurmak", "kahvehane kültürü", "berber sohbeti", "şans oyunları" "şahin marka otomobille drift atma", "mahallenin ara sokaklarında türk polisiyle kovalamaca" gibi unsurlar dikkat çekmektedir. Ayrıca tanıtımda çeşitli "Metinlerarasılık" unsurları da yer almaktadır. Berber sahnesinde türklerdeki "berber sadakati"ne yapılan vurgu üzerinden "Yüzüklerin Efendisi" filminde yer alan karakterlerden biri olan "Elf"'in traş edilmemesi yapımda yer alan bir metinlerarasılık örneği olarak değerlendirilmektedir.

Tanıtımda yer alan karakterler, dizinin aslına sadık olarak seçilirken; kostüm mekân ve dekor seçiminde tamamıyla türk kültürüne ait kodlamalara yer verilmektedir. Tanıtımda seçilen müzik, yapımın orjınal tanıtımında yer alan müzikten farklı olarak seçildiği görülmektedir. Tanıtımın ilk yarısında sözsüz olarak başlayan tanıtım müziğinin daha sonra, "arabesk rap" türüne evrilmesi yapımda yer alan kültürel kodlamalardan biri olarak ele alınmaktadır.

Burada yayıncı olarak Netflix'in hedefinin, Türk izleyicisini kültürel olarak uzak olduğu düşünülen fantastik dünyaya yaklaştırmak olduğu düşünülmektedir. Buradan hareketle, tanıtımın, yapımın fantastik ve bilim kurgusal yönünü olabildiğince rasyonelleştirerek ele aldığı ve kültürel kodlamalarla düzenleyerek yeniden izleyiciye aktarıldığı görülmektedir.

\section{Sonuç}

Bu bulgular göz önüne alındığında "Bright filmi ve Altered Carbon, Black Mirror" dizilerinin Türkiye tanıtımlarının katılımcılar nezdinde bașarılı olduğu görülmektedir. Otuz katılımcıdan sekizi dizilerin tanıtımlarını tamamen olumsuz şekilde değerlendirmiştir. Katılımcıların on tanesi ise bu tanıtımları olumlu değerlendirmiş ve ilgi çekici bulmuştur. Bunun yanı sıra katılımcıların bir kısmı yalnızca Black Mirror dizisine ait tanıtım filmini, bir kısmı yalnızca Altered Carbon'u ve belli bir kesimi de Bright filminin tanıtım filmini olumlu değerlendirmiş, diğer iki katılımcı ise yapımlarla ilgilenmediklerini dile getirmiş ve izleme alışkanlıklara uygun bulmamıștır. Bu veriler göz önüne alınarak; "Küyerelleşme" bağlamında kültürel kodlara yer verilerek hazırlanan Netflix tanıtımlarının belirlenen katılımcılar ışığında değerlendirilmesi sonucunda denilebilmektedir ki; bu tanıtımlar izleyicilerin yapımları izlemeyi tercih etmelerinde bir diğer deyişle izleme eğilimleri üzerinde olumlu bir etkiye sahip olmamaktadır. Küyerelleşme kavramı çerçevesinde ele alındığında, Türkiye özelinde yayınlanan tanıtımların, Türk izleyicileri üzerinde yapımı izlemeye yönlendirecek etki ve ilgiyi oluşturmadığı görülmektedir. Ayrıca farklı yaş grupları ve mesleklerden seçilen katılımcıların beğeni ve ilgilerinin oluşmasında 
asıl etkili olan unsurun, kültürel kodlarla oluşturulmuş olan tanıtımların değil, tümüyle kişisel beğeni ve zevkler olduğu saptanmıştır. Araştırma kapsamında kültürel kodlara yer vermesi açısından incelenen tanıtım filmlerinin, sosyal medyada almış olduğu etkileşim sayıları da dikkate alınarak çalışmaya dahil edilmiştir. Araştırma kapsamında incelenen üç gönderinin, paylaşıldıkları tüm sosyal medya platformları üzerinden değerlendirildiğinde, sosyal medyada en çok ilgi gören paylaşımın, Bright filminin tanıtımı için hazırlanan Orklar Aramızda adlı yapımın olduğu görülmektedir. Kullanıcılar tarafından en fazla ilgi gören ve paylaşılan ikinci yapım ise Esra Erol'lu Black Mirror tanıtım filmi olurken üç yapım arasında en az beğeni ve paylaşımı Altered Carbon dizisinin tanıtımı almıştır.

\section{Kaynakça}

Adorno, T.W. (2016). Kültür Endüstrisi Ve Kültür Yönetimi. İstanbul: İletişim Yayınevi.

Altered Carbon, Erişim: 7 Ekim 2019, https://dizimag5.co/altered-carbon0

Altunay, E., Oral, G. \& Yalçınkaya, M. (April, 2014). Eğitim Kurumlarında Mobbing Uygulamalarına İlişkin Nitel Bir Araştırma. Sakarya Üniversitesi Eğitim Fakültesi Dergisi. 4(1), 62-80.

Aydoğan, F. \& Akyüz, A. (2010). İkinci Medya Çağında İnternet. İstanbul: Alfa Yayıncılık.

Bauman, Z. (2017). Küreselleşme, Toplumsal Sonuçları. İstanbul: Ayrıntı Yayınevi.

Bright Filmi Hakkında Detaylar, Erişim:13 Ekim 2019, https://listelist.com/bright-filmihakkinda-detaylar/

Castells, M. (2005). Enformasyon Çağı: Ekonomi, Toplum ve Kültür. (Kılıç, Çev.). İstanbul: Bilgi Üniversitesi Yayınları.

Castells, M. (2007). Enformasyon Çă̆ı: Ekonomi, Toplum Ve Kültür / Binyılın Sonu. İstanbul: İstanbul Bilgi Üniversitesi Yayınları.

Castells, M. (2008). Enformasyon Çağı: Ekonomi, Toplum Ve Kültür / Kimliğin Gücü. İstanbul: İstanbul Bilgi Üniversitesi Yayınları.

Dijk, J. V. (2016). Ağ Toplumu. İstanbul: Kafka Yay.

Dilek, S.E. \& Kaygalak, S. (2015). Otel İşletmelerinde Küyerelleşme Yaklaşımı: İzmir İli Örneği. İşletme Fakültesi Dergisi 16(1), 1-22.

Dumanlı Kürkçü, D. (2013). Küreselleşme Kavramı Ve Küreselleşmeye Yönelik Yaklaşımlar. The Turkish Online Journal of Design, Art and Communication - TOJDAC, 3(2).

Geray, H. (2003). İletişim ve Teknoloji. Ankara: Ütopya Yayınevi.

Gezgin, S. (2005). Küreselleşmenin Medya Ve Toplum Üzerindeki Etkileri (Bölüm II). İletişim Fakültesi Dergisi, (22), 9-12.

Yeni Başlayanlar İçin Netflix, Erişim: 9 Eylül 2019, https://www.stuff.com.tr/yenibaslayanlar-icin-netflix/

Ilgaz Büyükbaykal, C. (2014). Küreselleșme Ve Küresel Çağda Medya. İstanbul: Derin Yayınları.

İçli, G. (2001). Küreselleşme Ve Kültür. C.Ü. Sosyal Bilimler Dergisi, 25(2), s.163 - 172.

Karasar, N. (2016). Bilimsel Araştırma Yöntemi:Kavramlar İlkeler Teknikler. Ankara: Nobel Yayınları.

Kaymakçı, O. (2007). Küreselleşme Üzerine Notlar. Ankara: Nobel Basımevi. 
McCrindle, M. \& Wolfinger, E. (2009). The ABC of XYZ: Understanding the Global Generations. Sydney: University of New South Wales Press.

Medyabey Official Website (2019,4 Kasım), 11 Aralık 2019 “Amazon Prime Videos Türkiye'de"

Melik Duyar Kimdir, Erişim: 9 Kasım 2018, http://www.megahafiza.com/melik-duyarkimdir.asp

Netflix Official Web Sayfası, Erișim: 9 Kasım 2018 "Netflix Kullanım Koșulları Klavuzu”

Özdemir, A. \& Eser, M. (2009). Küreselleşme. Bursa: Ezgi Kitabevi.

Robertson, R. (1997). Global Modernities. Sage Publications, 25-44.

Küreselleşmenin Ötesi Glokalleșme, Erişim: 20 Mayıs 2010, http://huseyinsevkitopuz. blogspot.com/2010/05/kuresellesmenin-otesi-glokallesme.html

Steger, M.B. (2013). Küreselleşme. Ankara: Dost Kitabevi Yayınları.

Tekin, H.H. (2006). Nitel Araştırma Yönteminin Bir Veri Toplama Tekniği Olarak Derinlemesine Görüşme. İstanbul Üniversitesi Sosyoloji Dergisi, 13(3), 101-116.

Ustakara, F. (2014). Küreselleşmenin Sürükleyici Gücü Halkla İlişkiler Ve Halkla İlişkileri Dönüştüren Küreselleşme. Global Media Journal: TR Edition 5(9).

Ülger, İ. (2000). Küreselleşme. İzmir: Etki Yayınevi.

Webtekno.com, Erișim: 4 Aralık 2019 "Netflix Türkiye'deki Kullanıcı Sayısını ve Bazı Önemli Bilgileri Açıkladı"

Varol, S. F. (2017). Medyanın Küreselleşmesi: Neden-Sonuç Ekseninde Bir Değerlendirme. Gümüşhane Üniversitesi İletişim Fakültesi Dergisi, 1 (5), 399-424.

Yılmaz, A. (2007). Romantizmden Gerçeğe Küreselleşme. Ankara: Minima Yayıncılık. 


\title{
The Effect of Globalizaton on Digital Platforms' Promotion of Content: The Netflix Example
}

\author{
Ümit Sarı (Asst. Prof. Dr.) \\ Petek Sancaklı (Res. Asst.)
}

\section{Extended Abstract}

The concept of globalization is one of the most important reasons why and how today's world takes its current form. The different definitions of the concept are based on a world order in which borders are invisible. According to Hirst and Thompson, globalization is one of a number of different international economic conjunctures which has existed since the 1860s (Dervişoğlu, 2013, p.5). Robertson, emphasized that hat globalization is a concept that both symbolizes the contraction of the world and also refers to the strengthening of world consciousness as a whole. Gordon Marshall defined the concept with the claim that it created a new consciousness. According to Marshall, globalization involves the formation of a new consciousness that grasps the world as a single place, and globalization has been described in this direction as a concrete structuring of the world as a whole, so, the world is a continuously re-establishing environment (Büyükbaykal, 2004, p. 6).

Another concept which is based on emphasizing local values and local against the cultural imperialism that emerged with globalization and which should be dealt with in the context of globalization of culture is the concept of "glocalization". Glocalization is defined as a combination of the concepts of globalization and localization, and it was first developed in the seventies as a result of the practices carried out by Japanese enterprises in different regions and to operate in regional markets (Dilek \& Kaygalak, 2014, p.4). Therefore, glocalization implies a marketing-oriented approach. It corresponds to the provision of a global product or service adapted to local characteristics, values or cultural expectations (Glocalization, 2018). With the concept of glocalization, it is emphasized that local and global related to each other mutually in different geographical locations (Büyükbaykal, 2014, p.80).

In the context of globalization, digitalization is one of the most important factors in shaping the world today. In addition to affecting various fields, digitalization has reshaped some sectors. Broadcasting is one of the most reshaped sectors. As a result of the contribution of digitalization to broadcasting technologies, digital platforms have emerged.

Netflix, which has achieved great success around the world, has become a structure that scientists working in the field of social sciences turn to research. The fact that Netflix is a digital broadcasting platform that has become a cultural carrier plays an important role in this. When evaluated in terms of content, Netflix includes productions produced in many countries of the world, especially American productions. The collection of content produced in many countries on a single digital platform is considered to be one of Netflix's key advantages.

Netflix's marketing strategies are considered as one of the most important reasons for its international success. In recent years, it has attracted the interest of researchers to create marketing strategies by using elements that are appropriate to the local values of the countries it serves. 
It is possible to accept glocalization as a result of globalization. Görmez (2005) argues that localization tendencies are not the opposite of globalization, but a natural consequence of it, and argues that the more globalized it is, the more localized it will be.

The rise of digital platforms worldwide has led to an increase in competition among themselves. Disney +, which started to serve in November 2019, has reached ten million subscribers in a short time. Although Netflix is an international leader, Disney + has become its main competitor. This is expected to cause Netflix to focus on its global marketing strategies to maintain its subscriber base.

At the point where global marketing strategies are blocked, glocal strategies have started to gain importance. It is among the goals of glocalization to ensure that the target audience turns towards the brand and establishes an emotional connection. Local elements address the sense of belonging and enable individuals to establish an emotional connection with the brand. Sociological factors are taken into consideration when developing marketing strategies. The use of sociological and cultural elements in the promotion of Netflix contents enables them to reach a large part of the society as well as subscribers. The local elements that it uses ensure the continuity of Netflix's subscribers, while at the same time bringing in new subscribers.

The impact of the term "glocalization" on the promotions of digital platforms in Turkey will be examined with the examples of local promotions for Netflix's original contents.

With their cultural encodings, these introductions provide important data in terms of the impact of the concept of glocalization on the content definition of digital platforms, and the dynamics of presentation and consumption. The research reveals whether such localization has any impact on the viewing habits of the audience or not.

Keywords: Globalization, Glocalization, Digital platforms, Netflix. 